\title{
Understanding Social Status: A Reply to Flemmen, Jarness and Rosenlund*
}

\author{
Tak Wing Chan \\ Department of Social Science \\ UCL Institute of Education
}

November 13, 2018

I am grateful to the Editor of the British Journal of Sociology, Dr Daniel Laurison, for giving me the space to respond to Flemmen, Jarness and Rosenlund (2018)'s (hereafter as FJR) critique of my work with John Goldthorpe on social status. In their article that appears in this issue of the $B J S$, FJR argue that Goldthorpe and I have misconstrued Max Weber's class-status distinction. They also propose a neo-Bourdieusian alternative that 'recognizes class and status as distinct aspects of stratification.' I will address both claims below. But let me start with a preliminary point.

Among other things, FJR argue that my work with Goldthorpe on status is 'very loosely connected to Weber's account', and that 'the key inspiration for [our] concept and measuring of status appears to come from the American sociology of stratification.' As Goldthorpe and I have labelled our approach as Weberian, I will provide some quotes from Weber to demonstrate that our research programme is indeed consistent with his ideas on social stratification. That is quite straightforward. But the really pertinent question is not whether we are true Weberians. After all, we are not in the business of ancestral worship. Rather, what matters is whether our rendition of the class-status distinction (or, for that matter, FJR's neo-Bourdieusian version) helps us understand important aspects of social inequality in contemporary societies. Keeping this in mind would, I believe, make for a more productive debate.

${ }^{*}$ I thank Gunn Elisabeth Birkelund and John Goldthorpe for helpful comments on an early draft. 


\section{The status order: past and present}

Goldthorpe and I understand the status order as a perceived and often accepted hierarchy of social superiority, equality and inferiority. As a form of social inequality, the status order has deep pre-industrial roots. Consider, for example, Laslett's (1965) description of Tudor and Stuart England. 'The ancien régime ... was marked by a very sharply delineated system of status, which drew firm distinctions between persons and made some superior, most inferior. There were various gradations, all authoritatively established and generally recognized' (Laslett, 1965, p. 22).

In everyday speech and in academic writings, the status order is often discussed in the language of class. But as Cannadine (1998, p. 22) points out, 'class as hierarchy' is the vernacular understanding of inequality 'which has had the widest, most powerful and most abiding appeal.' Under this view, the status order is 'a carefully graded ordering of rank and dignity' (p. 19), running 'from the reigning monarch to the humblest subject ... via the five different ranks of titled nobility, to baronets, knights, esquires, gentlemen, leading citizens and professionals, to yeoman, husbandmen and artisans, and so finally to cottagers, labourers, servants and paupers' (p. 26). This hierarchy was regarded as divinely sanctioned. People 'knew their place' in it and accepted it as the natural order of things. And 'it is these formal and informal hierarchies of prestige and status which people often have in mind when they speak of the "British class system"' (Cannadine, 1998, p. 22). ${ }^{1}$

Historians are in agreement that for centuries the status order is a key dimension of social stratification in Britain. But there is also a general recognition that with urbanisation, secularisation, affluence, universal suffrage, and other social changes (not least the almost complete disappearance of domestic servants as an occupation), deference is in long-term decline (McKibbin, 1998; Sutcliffe-Braithwaite, 2018). Take, for example, the so-called 'plebgate' in 2012, in which a senior MP, Andrew Mitchell, had to resign from his position as Government Chief Whip for allegedly calling police officers 'plebs' and telling them that they should 'learn their place' (Winnett, 2012). This bizarre incident reveals two things. First, some people are still quite statusconscious. Secondly, public expression of supercilious attitudes has become unacceptable.

Against this backdrop, the first question that we raise in our research programme is whether a status order still exists in contemporary British society (Chan and Goldthorpe, 2004). To address this question, we take

\footnotetext{
${ }^{1}$ By the same token, the language of social class as it is used in everyday speech is quite different from that in the technical sociological literature (see Section 4).
} 
our cue from Weber (1922, p. 305) who argues that 'status expresses itself through connubium and commensality', i.e. who sleeps with whom, and who eats with whom. Weber also gives an example of how status regulates social interaction: "only the resident of a certain street ("the Street") is considered as belonging to "society," is qualified for social intercourse, and is visited and invited' (Weber, 1922, p. 933).

There are plenty of literary and biographical examples that illustrate Weber's insight. For instance, in his 'autobiographical novel', Memoirs of A Fox-Hunting Man, Siegfried Sassoon (1928, pp. 10-11) recounts how he was brought up to be a gentleman by an aunt in Edwardian England. 'I was strictly forbidden to "associate" with the village boys. And even the sons of the neighbouring farmers were considered "unsuitable" ... I do not blame my aunt for this. She was merely conforming to her social code which divided the world into people whom one could "call on" and people who were "socially impossible".'

George Orwell, who describes himself as coming from a 'shabby-genteel family' in the 'lower-upper-middle class', makes a similar point. 'I was forbidden to play with the plumber's children; they were "common" and I was told to keep away from them. This was snobbish, if you like, but it also necessary, for middle-class people cannot afford to let their children grow up with vulgar accents' (Orwell, 1937, p. 117). ${ }^{2}$

Social status makes it difficult for a gentleman and someone from the lower ranks to become close friends. But it matters within the lower ranks too. Here is how Roberts (1971, p. 19) describes the various grades of manual workers in a Salford slum in the first quarter of the twentieth century, and their social interaction in pubs. 'On the social ladder after tradesmen and artisans came the semi-skilled workers ... and the various grades of unskilled labourers. These divisions could be marked in many public houses, where workers other than craftsmen would be frozen or flatly ordered out of those rooms in which journeymen forgathered. Each part of the tavern has its status rating; indeed, "he is only a tap-room man" stood as a common slur.'

Outside the British context, consider castes in India, which Weber regards as status groups par excellence. 'A caste is doubtless a closed status group. All the obligations and barriers that membership in a status group entails also exist in a caste, in which they are intensified to the utmost degree' (Weber, 1958, pp. 39-40). Béteille (1969, p. 31) points out, as have many other scholars, that ' $[\mathrm{t}]$ he social and cultural identity of each caste was preserved to a large extent by the rule of endogamy.' Indeed, castes regulate not only marriage, but social interaction in general. 'Limits were defined within which

\footnotetext{
${ }^{2}$ See Mullan (2014) for a discussion of status and rank in Jane Austen's novels.
} 
people could marry each other, eat together, accept food from each other, or live together in the same residential area' (Béteille, 1969, p. 231); in other words, connubium and commensality.

Given the above, the key Weberian idea that inform our approach is that intimate relationships, such as close friendship or marriage, are usually formed between people who regard each other as social equals (Runciman, 1997, pp. 156-157). And by studying the behavioural expression of status equality, we seek to map out the structure of status inequality. To operationalise this idea, we follow the pioneering work of Laumann (1966) and apply multidimensional scaling (MDS) analysis to a contingency table that cross-classifies the occupation of a sample of respondents with the occupation of their close friends.

Does this make our work more American than Weberian? I don't see how. Laumann is quite explicit that his 'principal concern ... is the study of status groups in Weber's terminology rather than economic class groupings' (Laumann, 1966, p. 4). I also think that FJR have failed to appreciate the very real differences between Laumann's social distance index and other occupational indices in 'the American sociology of stratification' (see Appendix A for a brief discussion).

\section{Key features of the status order}

The first dimension of our MDS analysis has two distinctive features. First, non-manual occupations rank above manual occupations. Secondly, within the non-manual range, professional occupations tend to rank above managerial occupations. In particular, we note that 'Managers and proprietors in services and Plant, depot and site managers are found together at the very end of the non-manual range' (Chan and Goldthorpe, 2004, pp. 389-390). As these are "rather clear "echoes" of the relatively explicit and well-defined status order that prevailed in British society from, say, the later nineteenth through to the mid-twentieth century' (Chan and Goldthorpe, 2004, p. 390), we argue that a status order, in the classical Weberian sense, still exists in contemporary British society.

FJR find our argument and evidence 'unconvincing'. They question whether we 'can pinpoint the specific role played by social honour by relying on occupations.' They maintain that 'it is not an intrinsic feature of the manual/non-manual divide that there is a difference of honour between them, just as it is not [a] given that professional qualifications signal more honour than managerial occupations.' And they think that our reference to 'historical echoes' is 'a rather vague justification'. 
Let me address these points in turn. Yes, it is true that social status might be based on attributes other than occupations. Race and ethnicity, for example, are important determinants of social status in many contemporary societies (see Laumann (1966) for a discussion on this point in the US context). In pre-industrial societies, birth or ancestry were important status markers, especially for the nobility and the gentry. Consider Gregory King's famous Social Table which describes the structure of English society in $1688 .{ }^{3}$ At the top of that table were the nobility and the gentry. But they accounted for no more than 4 or 5 percent of the population (Laslett, 1965, p. 27). The ranks below them are all identified by their occupations: merchants and traders by sea, persons in the law, clergymen, freeholders, persons in liberal arts and sciences, shopkeepers and tradesmen, artizans and handicrafts, and so on. Likewise, the status hierarchy outlined by Cannadine (see above) has the nobility and the gentry at the top, and the ranks below them are all occupational groups.

Roberts (1971) also describes the status hierarchy in Salford in occupational terms: tradesmen, artisans, craftsmen, journeymen, semi-skilled workers, and unskilled labourers. Regarding castes in India, Béteille (1969, p. 34) observes that '[e]ven today many castes bear occupational names.' More generally, Béteille (1996, p. 516) writes about the 'social rank of an occupation', 'the social esteem enjoyed by an occupation', and gives the example that '[j] udges, ambassadors and scientists do not earn higher incomes than entertainers or traders, yet they are more highly esteemed by virtue of the occupations in which they are engaged' (emphasis added). Thus, it should be clear that occupations have always been important markers of social status, especially in modern, anonymous, mass societies.

As regards the centrality of the manual/non-manual divide, Laslett (1965, p. 29) offers the following observation about pre-industrial England. 'Here was an economy conspicuously lacking in those devices for the saving of exertion which are so marked a feature of our own everyday life. The simplest operation needed effort; drawing water from the well, striking steel on flint to catch the tinder alight, cutting goose-feather quills to make a pen, they all took time, trouble and energy. The working of the land, the labour in the craftsmen's shop, were infinitely taxing' (Laslett, 1965, p. 29). Given all these, it should not be a surprise that 'the primary characteristic of the gentleman was that he never worked with his hands on necessary, as opposed to leisurely, activities.' Similarly, Cannadine (1998, p. 30) observes that 'the "great division" [is] between those who used their hands vs those who used the hands of others.' Even in contemporary societies, not getting 'dirty at

\footnotetext{
${ }^{3}$ Reproduced in, e.g., Laslett (1965, pp. 32-33) and Lindert and Williamson (1982).
} 
work' is a key determinant of a good job (Jencks et al., 1988).

Coming to the relative ranking of professional and managerial occupations, consider how Pear (1955) describes English Social Differences. 'The sharpest dividing lines in society lie between the professions, the trades and manual work' (p. 22). On the superiority of the professions to trades, Pear notes that '[a]t the period of the Regency, to be in trade still bore a social stigma' (p. 176). Indeed, 'one of the most important and least often mentioned aspects of English social stratification is the inferiority of the seller in the buyer-seller relationship. This principle determines the line drawn between people 'in trade,' and those in the professional classes-lawyers, accountants, etc' (Pear, 1955, p. 62).

Orwell (1937, pp. 114-115) also notes that '[b]fore the [First World W]ar you were either a gentleman or not a gentleman, and if you were a gentleman you struggled to behave as such, whatever your income might be ... Probably the distinguishing mark of the upper-middle class was that its traditions were not to any extent commercial, but mainly military, official and professional. People in this class owned no land, but they felt they were landowners in the sight of God and kept up a semi-aristocratic outlook by going into the professions and the fighting services rather than into trade.'

Recall our finding that 'Managers and proprietors in services and Plant, depot and site managers are found together at the very end of the non-manual range' (Chan and Goldthorpe, 2004, pp. 389-390). Managers and proprietors in services (say, restaurateurs or hoteliers) are people 'in trades'; while Plant, depot and site managers work in manual settings. These results are plainly consistent with the observations made by Pear and Orwell in the first half of the twentieth century.

I realise that all I have done in this section is to amplify a little the 'historical echoes' that Goldthorpe and I have referred to. It is clear that occupations have always been important markers of social status; and the key features of the first dimension of our MDS analysis resembles closely the status order in the past. These are good reasons to think that this dimension 'can be plausibly interpreted as reflecting a hierarchy of status' (Chan and Goldthorpe, 2004, p. 383). If FJR still regard these arguments and evidences as 'rather vague', I think it is incumbent upon them to come up with more substantive objections.

\section{Lifestyle vs intimate association}

FJR raise two further objections. The first is that Goldthorpe and I have 'produc[ed] a peculiar account where one expression of status honour ex- 
plains the other.' This is linked to their view that 'Weber regarded status as primarily expressed in lifestyle, and only secondarily in patterns of association.' I am not sure about the basis of the last claim. Consider the following passage.

[S]tatus honor is normally expressed by the fact that above all else a specific style of life is expected from all those who wish to belong to the circle. Linked with this expectation are restrictions on social intercourse ... These restrictions may confine normal marriages to within the status circle and may lead to complete endogamous closure' (Weber, 1922, p. 932).

In two adjoining sentences, Weber refers to both 'style of life' and 'restrictions on social intercourse'. I fail to see any compelling reason that would justify treating one of these indicators of social status as primary, and the other as only secondary.

Further exegesis of Weber's writings is probably unhelpful. But from the viewpoint of research design, there are good reasons to measure social status with data on intimate association. First, the meaning of lifestyle or cultural consumption indicators can change over time or vary across contexts. For example, on jazz, Peterson and Kern (1996, p. 901) argue that 'while its roots are clearly lowbrow, it is now taught in conservatories of music as highbrow and largely consumed as middlebrow.' Secondly, and more importantly, a key debate in the sociology of cultural consumption is precisely about the nature of the relationship between social status on the one hand and lifestyle and cultural consumption on the other. To evaluate the competing arguments in this debate, it is critical that we develop the key variables, i.e. social status and cultural consumption, independently of each other.

\section{The class-status distinction}

The other objection that FJR raise is that the CAMSIS (Cambridge Social Interaction and Stratification) scale 'does not distinguish between class and status, and it is explicitly premised on the view that "economic and social relations are embedded within each other".'

It is true that the CAMSIS scale and the scales of Laumann (1966) and Chan and Goldthorpe (2004) are all based on data on intimate association or social interaction. These scales are constructed in very similar ways. It is also true that the proponents of the CAMSIS scale interpret social interaction scales very differently to how Goldthorpe and I would interpret them. For example, Stewart et al. (1980, p. 28) claim that 'the Weberian distinction of 
classes ... from status groups ... is neither useful nor necessary.' Similarly, Bottero and Prandy (2003, p. 180) maintain that 'social interaction distance is taken as a stratification order in its own right' and that 'research has tended to eliminate the distinction between class and status, or the economic and the cultural, which was once seen as central analytically to conventional stratification theory.'

Whether Prandy and his colleagues are correct in their interpretation is an empirical question. The key is whether class and status help us understand different aspects of inequality in contemporary societies. Before we consider the empirical evidence, a few words on social class, as it is defined in the technical sociological literature, might be helpful.

Goldthorpe and I see social class as a structure of inequality that is rooted in the social relations of economic life, i.e. relations in labour markets and production units. The official UK National Statistics Socio-Economic Classification (NS-SEC) is developed with this as its starting point. In determining the class position of individuals under NS-SEC, employers are differentiated from self-employed workers or employees; and among employees, further differentiation are made according to the nature of their employment contract. ${ }^{4}$

While there is often very large inequality between social classes, NS-SEC, unlike the status order, is not consistently hierarchical in nature. For example, it is hard to say whether the self-employed is higher or lower than, say, routine non-manual or skilled manual workers. Moreover, although class and status are correlated with each other, there is also disagreement between them. '[T]he spread of status within classes is often quite considerable and that there is a good deal of overlap in status between classes, both in the case of the non-manual and manual classes considered separately and across the non-manual/manual divide' (Chan and Goldthorpe, 2004, p. 393). This means that class and status are not measuring the same thing. Two individuals in the same social class could have different social status, e.g. a site manager compared to a manager employed in a non-manual milieu. There are also cases where individuals of the same social status being found in different social classes, e.g. a self-employed plumber compared to an employee plumber. And since class and status are not the same thing, they are potentially useful for explaining social inequalities in different domains.

The evidence, pace Stewart et al. (1980) or Bottero and Prandy (2003), is that the Weberian distinction is not only conceptually cogent, but also empirically useful. For example, in Chan and Goldthorpe (2007a), we demon-

\footnotetext{
${ }^{4}$ NS-SEC is developed from the EGP class schema (Erikson and Goldthorpe, 1992). See Rose et al. (2005) for details about NS-SEC, and Goldthorpe (2007, ch. 5) for a theoretical discussion of employment relations and employment contracts.
} 
strate that it is social class (operationalised as the well known EGP class schema), not social status, which explains economic security (e.g. risks of recurrent or long-term unemployment), economic prospects (e.g. the ageearnings profile), and economic interests (e.g. the class-vote association). In Chan and Goldthorpe $(2005,2007 \mathrm{~b}, \mathrm{c}, \mathrm{d})$, we show that the opposite is true of cultural consumption of various kinds. We also show that while social class predicts left-right attitudes, it is social status which predicts libertarianauthoritarian attitudes (Chan and Goldthorpe, 2007a). This opens up a way to model what Weakliem (1991) calls the 'two lefts' in Western societies. In ongoing work, Chan et al. (2018) show that the class-status distinction helps explain the social bases of Brexit support.

Other researchers have also employed the class-status distinction to good effect. For example, Carella and Ford (2018) draw on the class-status distinction and show that 'support for the United Kingdom Independence Party (UKIP) is better understood as a status-based phenomenon than a classbased one.' Sacker et al. (2000, p. 1303) analyse linked census data from England and Wales and show that '[i]n men, social class ... was the most important influence on mortality. In women, social class based on individual employment relations and conditions showed only a weak gradient. Large differences in risk of mortality in women were found, however, when social position was measured [by the Cambridge scale].'

This result of Sacker et al. (2000) has been replicated and extended by Torssander and Erikson (2010). They recognise that education, income, class and status are related but distinct dimensions of social inequality. Using Swedish register data, they are able to show that 'for both sexes, there are clear net associations between education and mortality. Class and income show independent effects on mortality only for men and status shows an independent effect only for women' (Torssander and Erikson, 2010, p. 465). Reinforcing these results, Torssander and Erikson (2009) report a net association between men's mortality rate and their partner's social status, and a net association between women's mortality rate and their partner's social class position.

The class-status distinction also throws light on how family background impacts on children's educational attainment. Bukodi and Goldthorpe (2013) decompose the social origin effect into three parts: parental social class, parental social status and parental education. Based on an analysis of data from three British birth cohorts, they report that 'all three components of social origin have independent and distinctive effects on educational attainment, and ones that persist or change in differing ways across the cohorts' (Bukodi and Goldthorpe, 2013, p. 1024). Bukodi et al. (2014, p. 293) replicate this result for Sweden. Furthermore, they are able to show that "when 
cognitive ability is introduced into [the] analyses, parental class, status and education continue to have significant ... effects on the educational attainment of members of successive cohorts' (see also Bourne et al., 2018).

Overall, these studies show that the class-status distinction, as Goldthorpe and I have operationalised it, helps explain a range of phenomena that are of interest to sociologists. Can FJR explain these results with their neoBourdieusian framework and, if so, how?

\section{FJR's neo-Bourdieusian proposal}

In Chan and Goldthorpe (2010, p. 13), we point out the following. 'On Bourdieu's own account, his major work starts out from "an endeavour to rethink Max Weber's opposition" between class and status ... [Bourdieu] rejects Weber's view of the class positions of individuals or groups as being analytically and empirically separable from their status positions. Rather, status has to be seen as the symbolic aspect of the class structure. And instead of class and status being linked, as Weber puts it, "in the most varied ways" ... Bourdieu insists on their necessarily close correspondencea correspondence which is in fact essential to his homology argument in regard to social and cultural hierarchies.'

Our reading of Bourdieu is shared by some Bourdieusian scholars. For example, Weininger (2005, p. 84) observes that, 'Bourdieu thus interprets Weber's contrast between class and status in terms of a distinction between the material (or "economic") and the symbolic. He maintains, moreover, that these should not be viewed as alternative types of stratification ... To the contrary, the distinction between class and status group must be seen purely as an analytical convenience - one which Bourdieu, moreover, is inclined to disallow.'

Similarly, Swartz (1997, p. 45) argues that '[w] hereas Weber thought of class and status as distinct ideal types that can be used to compare and contrast historically specific societies, Bourdieu posits a fundamental principle linking class and status. Status is a sort of veneer that legitimates class interest by presenting it under the disguise of disinterestedness. Status groups and status are classes and class distinctions in disguise' (emphasis added).

FJR quote both Swartz (1997) and Weininger (2005) in their paper. So how do they come to their neo-Bourdieusian framework which recognizes 'class and status as distinct aspects of stratification'? The answer to this question is not entirely clear to me. But in several densely written pages that discount 'a superficial reading' and invoke numerous Bourdieusian concepts, such as habitus, social space, the various forms of capital, symbolic power, 
... FJR argue that 'Bourdieu's homology thesis offer an excellent means to unpack the different ways in which class and status differences combine - and also the ways in which they do not.'

I have read these pages multiple times. But I must confess that I, for one, am none the wiser as to how this neo-Bourdieusian class-status distinction works. ${ }^{5}$ But one thing is clear. Within this framework, social class needs to be understood in a certain Bourdieusian way. 'Bourdieu advanced a model of social class that does not operationalize it in terms of position in markets or productive relations as in conventional Weberianism, but in social relations more broadly ... It is thus not a model of class situation in the narrow Weberian sense - as essentially a market situation - but it is more in line with how the neo-Weberian closure theorist, Murphy (1988), defines social class as combining all major forms of domination in a society.' Likewise, social status needs to be interpreted in certain Bourdieusian ways too, as 'embodied cultural capital', 'symbolic power' and 'the space of lifestyles interpreted as a space of (possible) "status situations",' and so on.

With one Bourdieusian concept after another tumbling onto the page, this is too much exegesis for my taste. But a key question remains. How do we evaluate this neo-Bourdieusian framework? What would count as evidence against it? As mentioned above, a central focus of sociological research of cultural consumption is the nature of the relationship between social stratification (be it class or status) and cultural consumption. Bourdieu's homology argument is one of several arguments in this literature. If homology is baked into the definition and measurement of class and status, how do we test the competing arguments fairly? In fact, is the homology argument even falsifiable in this framework?

In any case, the upshot of FJR's argument are these elliptical claims. '[W]e can thus appreciate that Bourdieu's model offers distinct analytical concepts for class and status divisions. But he suggests that these two spaces actually correspond in a particular sense, in that the principles that structure the two spaces are in fact the same.' 'With Distinction, Bourdieu put

\footnotetext{
${ }^{5}$ In grappling with another French intellectual tradition, Jerry Cohen (2002, p. 322) writes, 'The ideas that the Althusserians generated, for example, of the interpellation of the individual as a subject, or of contradiction and overdetermination, possessed a surface allure, but it often seemed impossible to determine whether or not the theses in which those ideas figured were true, and, at other times, those theses seemed capable of just two interpretations: on one of them they were true but uninteresting, and, on the other, they were interesting, but quite obviously false. (Failure to distinguish those opposed interpretations produces an illusory impression of interesting truth.)' Substitute interpellation, contradiction, and overdetermination with habitus, social space, or symbolic violence, what Cohen says about reading Althusser and Altusserians also describes my experience of reading Bourdieu and many Bourdieusians.
} 
these ideas into practice by offering an empirical analysis meant to demonstrate that class and status are in fact different aspects of the same reality' (emphases added).

So after all the mental gymnastics, we seem to have come back to the view of Chan and Goldthorpe (2004, 2010), Weininger (2005) and Swartz (1997): that, from the Bourdieusian standpoint, there is a very close correspondence between class and status or, as Weininger puts it, class and status are 'yoked together'. If that is the case, why the tortuous (and torturous) argument?

But perhaps FJR do mean to say that, under their neo-Bourdieusian framework, class and status really are distinct, but they are also the same. In which case, I could only refer them to an exchange between Sidney Morgenbesser and a Maoist student in the 1970s. Apparently, the student asked Morgenbesser 'if he disagreed with Chairman Mao's saying that a proposition can be true or false at the same time. Dr. Morgenbesser replied, "I do and I don't"' (Martin, 2004).

Let me finish with a technical point. The data that FJR analyse were collected in a telephone survey from 2011. Only 10 percent of the people contacted in that survey answered the relevant questions, which is a very low response rate. But FJR claim that with post-survey weighting, the univariate distribution of the variables in their survey on the 'political party one would vote for' and 'how often one reads news online' are 'practically identical' with nationally representative data from Statistics Norway. And so they conclude that "weighting works and we thus have a data set that is nationally representative in terms of the issues we are looking at.'

Not so fast. Post-survey weighting is not a panacea. Much depends on the underlying mechanism that generates the nonresponse in the first place. As Groves (2006, p. 653) points out, '[a]ll of these [post-survey] adjustment techniques require assumptions that groups of respondents and nonrespondents share response propensities and distributional properties on survey measures ... In practice, the assumptions underlying the adjustment procedures are generally untestable ...Further, some adjustments may make matters worse.'

Moreover, '[w]ithin the same survey, different sample estimates can be subject to different nonresponse biases. Some, unrelated to the propensity to respond, can be immune from biasing effects of nonresponse; others, in the same survey, can be subject to large biases' (Groves, 2006, p. 649). Given these considerations, the very low response rate of FJR's survey remains a cause for concern. No matter what theoretical framework we work with, we should all take data quality issues more seriously. 


\section{References}

Béteille, A. (1969). Castes, Old and New: Essays in Social Structure and Social Stratification. Asia Publishing House, London.

Béteille, A. (1996). The mismatch between class and status. British Journal of Sociology, 47(3), 513-525.

Blau, P. M. and Duncan, O. D. (1967). The American Occupational Structure. John Wiley and Sons, New York.

Bottero, W. and Prandy, K. (2003). Social interaction distance and stratification. British Journal of Sociology, 54(2), 177-197.

Bourne, M., Bukodi, E., Betthäuser, B., and Goldthorpe, J. H. (2018). 'persistence of the social': the role of cognitive ability in mediating the effects of social origins on educational attainment in Britain. Research in Social Stratificaion and Mobility. in press.

Bukodi, E. and Goldthorpe, J. H. (2013). Decomposing 'social origin': the effects of parents' class, status, and education on the educational attainment of their children. European Sociological Review, 29(5), 1024-1039.

Bukodi, E., Erikson, R., and Goldthorpe, J. H. (2014). The effects of social origin and cognitive ability on educational attainment: evidence from Britain and Sweden. Acta Sociologica, 57(4), 293-310.

Cannadine, D. (1998). Class in Britain. Yale University Press, New Haven.

Carella, L. and Ford, R. (2018). Who are the 'left behind'? The status stratification of radical right support. Unpublished manuscript.

Chan, T. W. (2010). The social status scale: its construction and properties. In T. W. Chan, editor, Social Status and Cultural Consumption, chapter 2. Cambridge University Press, Cambridge.

Chan, T. W. and Goldthorpe, J. H. (2004). Is there a status order in contemporary British society? Evidence from the occupational structure of friendship. European Sociological Review, 20(5), 383-401.

Chan, T. W. and Goldthorpe, J. H. (2005). The social stratification of theatre, dance and cinema attendance. The Cultural Trends, 14(3), 193212. 
Chan, T. W. and Goldthorpe, J. H. (2007a). Class and status: the conceptual distinction and its empirical relevance. American Sociological Review, 72(4), 512-532.

Chan, T. W. and Goldthorpe, J. H. (2007b). Social status and newspaper readership. American Journal of Sociology, 112(4), 1095-1134.

Chan, T. W. and Goldthorpe, J. H. (2007c). Social stratification and cultural consumption: music in England. European Sociological Review, 23(1), 119.

Chan, T. W. and Goldthorpe, J. H. (2007d). Social stratification and cultural conumption: the visual arts in England. Poetics, 35(2/3), 168-190.

Chan, T. W. and Goldthorpe, J. H. (2010). Introduction: social status and cultural consumption. In T. W. Chan, editor, Social Status and Cultural Consumption, chapter 1. Cambridge University Press, Cambridge.

Chan, T. W., Henderson, M., Sironi, M., and Kawalerowicz, J. (2018). Understanding the social and cultural bases of Brexit. Unpublished paper.

Cohen, G. A. (2002). Deeper into bullshit. In L. Overton and S. Buss, editors, Contours of Agency: Essays on Themes From Harry Frankfurt, chapter 12, pages 321-344. MIT Press, Cambridge, MA.

Duncan, O. D. (1961). A socioeconomic index for all occupations. In A. Reiss, editor, Occupations and Social Status. Free Press, New York.

Erikson, R. and Goldthorpe, J. H. (1992). The Constant Flux: A Study of Class Mobility in Industrial Societies. Clarendon Press, Oxford.

Flemmen, M., Jarness, V., and Rosenlund, L. (2018). Class and status: on the misconstrual of the conceptual distinction and a neo-Bourdieusian alternative. British Journal of Sociology. in press.

Goldthorpe, J. H. (2007). Social class and the differentiation of employment contracts. In J. H. Goldthorpe, editor, On Sociology, volume 2, chapter 5, pages 101-124. Stanford University Press, Stanford, second edition.

Goldthorpe, J. H. and Hope, K. (1974). The Social Grading of Occupations: A New Approach and Scale. Clarendon Press, Oxford.

Groves, R. M. (2006). Nonresponse rates and nonresponse bias in household surveys. Public Opinion Quarterly, 70(5), 646-675. 
Hauser, R. M. and Warren, J. R. (1997). Socioeconomic indexes for occupations: a review, update, and critique. Sociological Methodology, 27, $177-298$.

Hodge, R. M., Siegel, P. M., and Rossi, P. H. (1964). Occupational prestige in the united states, 1925-63. American Journal of Sociology, 70(3), 286-302.

Jencks, C., Perman, L., and Rainwater, L. (1988). What is a good job? A new measure of labor-market success. American Journal of Sociology, 93(6), 1322-1357.

Laslett, P. (1983/1965). The World We Have Lost, Further Explored. Routledge, London, third edition.

Laumann, E. O. (1966). Prestige and Association in an Urban Community. Bobbs-Merrill, Indianapolis.

Lindert, P. H. and Williamson, J. G. (1982). Revising England's social tables, 1688-1812. Explorations in Economic History, 19, 385-408.

Martin, D. (2004). Sidney Morgenbesser, 82, kibitzing philosopher, dies. The New York Times. Published 4 August 2004, retrieved 14 September 2018.

McKibbin, R. (1998). Classes and Cultures: England 1918-1951. Oxford University Press, Oxford.

Mullan, J. (2014). Status, rank and class in Jane Austen's novels. https://www.bl.uk/romantics-and-victorians/articles/status-rankand-class-in-jane-austens-novels.

Orwell, G. (1986/1937). The Road to Wigan Pier. Penguin, London.

Pear, T. H. (1955). English Social Differences. George Allen and Unwin, London.

Peterson, R. A. and Kern, R. M. (1996). Changing highbrow taste: from snob to omnivore. American Sociological Review, 61(5), 900-907.

Prandy, K. and Lambert, P. S. (2003). Marriage, social distance and the social space: an alternative derivation and validation of the cambridge scale. Sociology, 37(3), 397-411.

Reiss, A., editor (1961). Occupations and Social Status. Free Press, New York. 
Roberts, R. (1990/1971). The Classic Slum. Penguin, Harmondsworth.

Rose, D., Pevalin, D. J., and O'Reilly, K. (2005). The NS-SEC: Origins, Development and Use. Palgrave Macmillan, Basingstoke.

Runciman, W. G. (1997). Applied Social Theory, volume 3 of A Treatise On Social Theory. Cambridge University Press, Cambridge.

Sacker, A., Firth, D., Fitzpatrick, R., Lynch, K., and Bartley, M. (2000). Comparing health inequality in men and women: prospective study of mortality 1986-96. BMJ, 320(7245), 1303-1307.

Sassoon, S. (1928). Memoirs of A Fox-Hunting Man. Faber and Faber, London.

Sørensen, A. B. (2001). The basic concepts of stratification research. In D. B. Grusky, editor, Social Stratification: Class, Race and Gender in Sociological Perspective, pages 287-300. Westview, Oxford, second edition.

Stewart, A., Prandy, K., and Blackburn, R. M. (1980). Social Structure and Occupations. Macmillan, London.

Sutcliffe-Braithwaite, F. (2018). Class, Politics, and the Decline of Deference in England, 1968-2000. Oxford University Press, Oxford.

Swartz, D. (1997). Culture and Power: The Sociology of Pierre Bourdieu. University of Chicago Press, Chicago, IL.

Torssander, J. and Erikson, R. (2009). Marital partner and mortality: the effects of the social positions of both spouses. Journal of Epidemiology and Community Health, 63, 992-998.

Torssander, J. and Erikson, R. (2010). Stratification and mortality: a comparison of education, class, status, and income. European Sociological Review, 26(4), 465-474.

Treiman, D. J. (1977). Occupational Prestige in Comparative Perspective. Academic Press, New York.

Weakliem, D. L. (1991). The two lefts? Occupation and party choice in France, Italy, and the Netherlands. American Journal of Sociology, 96(6), $1327-1361$.

Weber, M. (1958). The Religion of India: The Sociology of Hinduism and Buddhism. Free Press, Glencoe, IL. 
Weber, M. (1968/1922). Economy and Society. University of California Press, Berkeley and Los Angeles.

Weininger, E. B. (2005). Pierre Bourdieu on social class and symbolic violence. In E. O. Wright, editor, Approaches to Class Analysis, chapter 4, pages 116-165. Cambridge University Press, Cambridge.

Winnett, R. (2012). Police log reveals details of Andrew Mitchell's 'pleb' rant. The Telegraph. Published 24 September 2012, retrieved 2 September 2018.

\section{A Occupational indices}

A main focus of quantitative social stratification research in the 1950s and 1960s was the estimation of occupational prestige (Reiss, 1961). Typically, the data were obtained from sample surveys in which the respondents were asked 'to judge an occupation as having excellent, good, average, somewhat below average, or poor standing ... One indicator of prestige position is the proportion of respondents ...giving either an "excellent" or a "good" response ...' (Hodge et al., 1964). This body of research has produced some useful outputs, including the Standard International Occupational Prestige Scale (SIOPS) and the very interesting finding that occupational prestige ranking is very similar across countries (Treiman, 1977).

But there are conceptual and practical issues with occupational prestige research. Conceptually, it is not clear just what the respondents have in mind when they rate the occupations. As Goldthorpe and Hope (1974) argue, it is quite plausible that the respondents are evaluating in some general sense how good or desirable the occupations are. But occupational desirability is different from social status in the classical Weberian sense (Sørensen, 2001). More practically speaking, there are often hundreds of occupational titles in occupational classification schemes. But occupational prestige surveys usually cover several dozens occupational titles at a time. So the prestige score of many occupations are unknown.

To 'fill in' the missing prestige scores, Duncan (1961) devises a method that makes use of regression analysis and census data. To elaborate, for those occupations with known prestige scores, the prestige scores are regressed on some central tendency measures of the income and educational attainment of the incumbents of those occupations. It turns out that the regression coefficients for income and educational attainment are very similar. These 
coefficients are then used, along with known income and educational attainment data (from census), to predict the prestige ratings of those occupations not covered in occupational prestige surveys. This leads to the Duncan's Socio-Economic Index (SEI) which, together with the path analytic model (Blau and Duncan, 1967), become the mainstay of status attainment research in the following decades.

The social interaction scales estimated by by Laumann (1966), Stewart et al. (1980), Chan and Goldthorpe (2004) are very different. They are typically constructed as follows. Researchers start with a contingency table which cross-classifies the occupations of a sample of respondents with the occupations of their intimate associates (e.g. close friend or spouse/partner). They then calculate the 'social distance' between every pair of occupations by comparing the occupational distribution of the associates. Finally, the half-matrix of social distances are analysed using multidimensional scaling, correspondence analysis, association models, etc (see e.g. Chan, 2010, for details). The first dimension extracted in this analysis is the social interaction index.

Thus, in terms of conceptualisation, the nature of the data used and construction method, social interaction indices are very different from both occupational prestige scale or SEI. As Prandy and Lambert (2003, p. 400) point out, social interaction scales represent 'a distinctive approach; [they are] not constructed out of people's subjective judgements, as in the measurement of social status or prestige, or out of an assessment of material factors and economic relationships, as in the construction of a class schema.' I should add that, social interaction scales are also very different from SEI, which is really a synthetic scale, based on the weighted mean of summary measures of income and educational attainment. For these reasons, FJR are wrong to lump Laumann together with Warner, and Blau and Duncan under the umbrella heading 'American sociology of stratification'. These approaches are very different from each other. For further discussion of occupational indices, see Hauser and Warren (1997). 